\title{
Filaggrin null mutations are associated with atopic dermatitis and elevated levels of IgE in the Japanese population: a family and case-control study
}

\author{
Hisako Enomoto · Kenji Hirata - Kenta Otsuka · Toshiharu Kawai • \\ Takenori Takahashi · Tomomitsu Hirota · Yoichi Suzuki · Mayumi Tamari • \\ Fujio Otsuka $\cdot$ Shigeharu Fujieda $\cdot$ Tadao Arinami $\cdot$ Emiko Noguchi
}

Received: 24 December 2007/Accepted: 17 March 2008/Published online: 3 June 2008

(C) The Japan Society of Human Genetics and Springer 2008

\begin{abstract}
Filaggrin ( $F L G)$ plays an important role in the barrier function of the skin. Several loss-of-function mutations in the FLG gene have been identified in patients with ichthyosis vulgaris, and these null mutations are associated with atopic dermatitis (AD) development. In this study, we examined tag single nucleotide polymorphisms (tSNPs) and null mutations in FLG for possible associations with AD and atopic phenotypes in a Japanese population. Transmission disequilibrium test of $105 \mathrm{AD}$ families showed that the null allele of the S2554X variant of FLG tended to be overtransmitted to AD-affected offspring; however, the $P$ value did not reach statistical significance. In a casecontrol comparison of $376 \mathrm{AD}$ cases and 923 nonallergic controls, the null allele of S2554X was significantly
\end{abstract}

H. Enomoto - K. Hirata - K. Otsuka - T. Kawai · T. Arinami ·

E. Noguchi $(\square)$

Department of Medical Genetics,

Graduate School of Comprehensive Human Sciences,

University of Tsukuba, 1-1-1 Tennodai, Tsukuba, Ibaraki, Japan

e-mail: enoguchi@md.tsukuba.ac.jp

H. Enomoto · T. Takahashi · F. Otsuka

Department of Dermatology,

Graduate School of Comprehensive Human Sciences,

University of Tsukuba, Tsukuba, Ibaraki, Japan

T. Hirota $\cdot$ M. Tamari

Laboratory of Genetics of Allergic Disease,

RIKEN SNP Research Center, Yokohama, Japan

Y. Suzuki

Department of Public Health,

Chiba University Graduate School of Medicine,

Chiba, Japan

S. Fujieda

Departments of Otorhinolaryngology and Immunology,

University of Fukui Faculty of Medical Sciences, Fukui, Japan associated with $\mathrm{AD}(P=0.0012)$, and the association was strengthened in subjects with $\mathrm{AD}$ alone $(P=0.000024)$. We found that 3321delA and S2554X were also associated with elevated levels of immunoglobulin E (IgE). Combined null mutation carriers were observed more in AD patients and in subjects with high IgE than in control subjects. The combined $P$ value for the family and case-control data was significant for the S2554X and combined null mutations. Our data further support the importance of $F L G$ in $\mathrm{AD}$ development.

Keywords Filaggrin - Atopic dermatitis .

Null mutations · Ichthyosis vulgaris · IgE

\section{Introduction}

Atopic dermatitis (AD) is an itchy, chronic, inflammatory skin disease categorized as an atopic disease, along with atopic asthma and rhinitis. The prevalence of AD has been studied in a wide variety of populations, and its reported frequency ranges from $0.73 \%$ to $23 \%$ (Levy et al. 2003). The 12-month prevalence of symptoms of atopic eczema in Japanese children 6-7 years of age was $16.9 \%$, the second highest after Sweden (Williams et al. 1999). Twin and family studies have indicated that predisposition for AD is highly heritable (Larsen et al. 1986), with a heritability value of 0.72 (Nystad et al. 2005). However, details regarding inheritance of $\mathrm{AD}$ remain unclear.

To identify susceptibility genes for $\mathrm{AD}$, genome-wide linkage studies and candidate gene approaches have been used. To date, five genome-wide linkage studies have been performed in Caucasian populations (Lee et al. 2000; Cookson et al. 2001; Bradley et al. 2002; Haagerup et al. 2004) and a Japanese population (Enomoto et al. 2007), 
and evidence for linkage to $\mathrm{AD}$ was obtained for several chromosomal regions. Several candidate genes, mainly immune-related genes including interleukin (IL)-4 (IL4), IL13, IL5, IL12B, and serine protease inhibitor Kazal-type 5 (SPINK5 ) have been examined for possible association with AD (Morar et al. 2006). Recent studies have emphasized the importance of skin-barrier function in $\mathrm{AD}$ development. Loss-of-function mutations in the filaggrin gene $(F L G)$ were found to be associated with $\mathrm{AD}$ in independent populations (Irvine 2007). FLG protein is present in the granular layers of the epidermis, and the keratohyalin granules in the granular layers are predominantly composed of the 400-kDa polyprotein, profilaggrin (Dale et al. 1985; Listwan and Rothnagel 2004; Candi et al. 2005). On the differentiation of keratinocytes, profilaggrin is dephosphorylated and cleaved into 10-12 essentially identical $37-\mathrm{kDa}$ filaggrin peptides. FLG proteins aggregate the keratin cytoskeleton system to form a dense protein-lipid matrix that is crosslinked by transglutaminases to form the cornified cell envelope (Candi et al. 2005). This structure prevents epidermal water loss and impedes the entry of allergens, toxic chemicals, and infectious organisms. Therefore, FLG is a key protein in terminal differentiation of the epidermis and skin-barrier function (Gan et al. 1990).

FLG is located on human chromosome 1q21 (Compton et al. 2002), for which a previous genome-wide linkage study found evidence of linkage with $\mathrm{AD}$ (Cookson et al. 2001). The chromosome 1q21 region harbors the epidermal differentiation complex (EDC), which is a dense cluster of genes involved in the terminal differentiation of the epidermis and formation of the stratum corneum, the outermost dead cell compartment of the skin where the main skin barrier function occurs (Mischke et al. 1996). FLG is located in the EDC. Recently, we performed a genomewide linkage analysis of Japanese families with $\mathrm{AD}$ and found weak evidence for linkage on 1q24 (Enomoto et al. 2007) near $1 \mathrm{q} 21$.

$F L G$ was initially identified as a susceptibility gene for ichthyosis vulgaris (Smith et al. 2006), a disorder of keratinization, and Palmer et al. (2006) reported that two nonsense mutations in FLG-R501X and 2282del4-were associated with $\mathrm{AD}$ development in a Caucasian population. These mutations showed a combined allele frequency of $\sim 4 \%$ in populations of European ancestry, and the variants were greatly overrepresented in the cohort with $\mathrm{AD}$, indicating a highly significant dominant risk of $\mathrm{AD}$ (Palmer et al. 2006). FLG null alleles X501 and 2282del4 occur at higher frequency in individuals with both asthma and $\mathrm{AD}$ than in individuals with asthma alone (Palmer et al. 2006). The R501X and 2282del4 variants were absent in non-European populations, such as those of Asian or African origin.
The associations of $F L G$ null alleles with AD development have been replicated in several European populations (Marenholz et al. 2006; Ruether et al. 2006; Sandilands et al. 2006; Weidinger et al. 2006; Barker et al. 2007; Stemmler et al. 2007; Weidinger et al. 2007). FLG null alleles were also found to be associated with elevated levels of immunoglobulin E (IgE) (Weidinger et al. 2006, 2007) and allergic sensitization (Weidinger et al. 2006), and Marenholz et al. (Marenholz et al. 2006) reported that those mutations predispose carriers to asthma, allergic rhinitis, and allergic sensitization only in the presence of AD. Other FLG null mutations have also been found to be associated with $\mathrm{AD}$ in a Caucasian population (Sandilands et al. 2007). In a Japanese population, the 3321delA and S2554X mutations were associated with ichthyosis vulgaris and AD (Nomura et al. 2007). Most of the previous studies related to FLG mutations were conducted with European populations, and studies of $F L G$ variants other than the null mutations in relation with $\mathrm{AD}$ have not been conducted.

In this study, we examined tag single nucleotide polymorphisms (tSNPs) and null mutations in FLG for possible associations with $\mathrm{AD}$ and atopic phenotypes in a Japanese population.

\section{Materials and methods}

Subjects

Probands in the $\mathrm{AD}$ families were patients with $\mathrm{AD}$ who visited the Dermatology Department of the University Hospital of Tsukuba (Japan) and dermatology departments of several hospitals in Ibaraki, Japan. AD was diagnosed in subjects according to the criteria of Hanifin and Rajka (1980). All patients had pruritus, typical appearance of AD, and a tendency toward chronic or chronically relapsing dermatitis. A full verbal and written explanation of the study was given to all family members interviewed, and 105 families (381 members) gave informed consent and participated in this study. The mean age of the probands and their siblings was 13.3 years (range $0.9-42$ years). For a case-control study, 376 independent AD patients (ages 16-64 years, mean 29.7 years) were recruited. Control subjects for the case-control study were 923 healthy adults (ages 19-78 years, mean 46.2 years) with no history of any allergic disease. A full verbal and written explanation of the study was given to patients and all family members interviewed, and all provided informed consent. This study was approved by the Committee of Ethics of the University of Tsukuba. The subjects for the case-control study were classified according to AD alone, elevated total serum IgE level ( $>1,000 \mathrm{IU} / \mathrm{l})$, and early onset $(<2$ years of age). Among 376 patients with $\mathrm{AD}$, the number of patients with 
AD alone (i.e., AD patients without another atopic disease such as asthma and rhinitis) was 75 (20\%). The number with an elevated total serum IgE was $212(56 \%)$, and the number with early onset was $112(30 \%)$.

\section{Genotyping}

Genomic DNA was extracted from peripheral blood leukocytes or oral brushed cells using standard protocol. R501X and 2282del4 were genotyped by restriction enzyme digestion of polymerase chain reaction (PCR) products amplified from DNAs of 96 unrelated Japanese AD patients. The R501X and 2282del4 variants were PCR amplified with the following primer sequences, 5'-CTGGAGGAAGACA AGGATCG- $3^{\prime}$ and 5'-TTGTCTGCTTGCACTTCTGG-3' for the R501X and 5'-ATCAGGCACTCGTCACACAC-3' and $5^{\prime}$-AGTGCCTGGAGTTGTCTCGT-3' for 2282 del4. PCR products were digested with NlaIII for R501X and DraIII for $2282 \mathrm{del} 4$ at $37^{\circ} \mathrm{C}$ for $16 \mathrm{~h}$. Digested PCR fragments were subjected to agarose gel electrophoresis and visualized by ethidium bromide staining and ultraviolet transillumination. Expected product sizes for R501 were 213 and 32 bp and for X501 allele were 177, 36, and 32 bp. Expected product sizes for the wild-type allele of 2282del4 were $458 \mathrm{bp}$, and for the deletion allele were 240 and 214 bp. We genotyped 3321delA with sizing of a fluorescently labeled PCR fragment on an Applied Biosystems 3100 DNA Sequencer (Foster City, CA, USA) as described previously (Nomura et al. 2007). Genotype information for the FLG region in Asian populations (Japanese and Chinese) was downloaded from the HapMap database (http://www.hapmap.org/cgi-perl/gbrowse/hapmap_B36/), and tSNPs were selected with Tagger software (de Bakker et al. 2005) implemented in Haploview software (Barrett et al. 2005) with an $r^{2}$ threshold of 0.8 and allele frequencies of 0.05. Tag SNPs (rs11582620, rs11586114, rs1933064, rs2065958, rs3814299, rs12730241) were genotyped with TaqMan Assay-on-Demand ${ }^{\text {TM }}$ SNP Typing Systems (Applied Biosystems). We genotyped S2554X on a TaqMan Assay-by-Design system for SNP genotyping (Applied
Biosystems), with the following primer sequences: forward, 5'-CGGCTCCAGGCACTCA-3', reverse, 5'-ATCCCCAG TTCCTGCTTGTC- $3^{\prime}$ reporter 1 (VIC), 5'-CCCCTCTGA TTGTC- $3^{\prime}$ and reporter 2 (FAM), 5'-CCCCTCTCATTG TC-3'. Genotyping accuracy was confirmed based on the direct sequences of samples obtained from carriers and noncarriers of the S2554X null mutation.

\section{Statistical analysis}

Transmission disequilibrium test (TDT) and pedigree disequilibrium test (PDT) were performed with the unphased program (http://www.mrc-bsu.cam.ac.uk/personal/frank/ software.unphased/). Linkage disequilibrium (LD) between SNPs, as expressed by D', was calculated with Haploview software (Barrett et al. 2005). The significance of differences in the allele frequencies between case and control groups in case-control comparisons was determined by the $\chi^{2}$ test. To combine family and case-control data, control alleles in $\mathrm{AD}$ families were constructed as nontransmitted parental allele and case alleles as transmitted parental alleles as described by Kirov et al. (Kirov et al. 1999).

\section{Results}

The X501 and 2282del4 alleles were not identified in 96 independent Japanese patients with AD. The allele frequencies for all SNPs in parents in AD families and in controls did not deviate from Hardy-Weinberg equilibrium predictions $(P>0.05)$. TDT revealed that the minor alleles of rs2065958 and rs12730241 were overtransmitted to ADaffected offspring $(P<0.05$, Table 1$)$. However, these results were not replicated in the AD case-control study (Table 2). In the AD case-control study, we genotyped two nonsynonymous SNPs, rs2065958 and rs3814299, because rs12730241 is in nearly complete LD with rs2065958 $\left(r^{2}=0.95\right)$. The null allele of S2554X tended to be overtransmitted to $\mathrm{AD}$-affected offspring, though the $P$ value
Table 1 Transmission disequilibrium test (TDT) and pedigree disequilibrium test (PDT) analysis of the $F L G$ polymorphisms in Japanese atopic dermatitis (AD) families

SNP single nucleotide polymorphism, $T$ number of alleles transmitted to affected children, $N T$ number of alleles not transmitted to affected children

\begin{tabular}{llllllll}
\hline Polymorphism & SNP & Allele & $\begin{array}{l}\text { Allele } \\
\text { frequency }\end{array}$ & T & NT & TDT $P$ value & PDT $P$ value \\
\hline rs11582620 & A/G & A & 0.89 & 41 & 26 & 0.066 & 0.059 \\
rs11586114 & A/G & G & 0.55 & 90 & 78 & 0.35 & 0.11 \\
rs1933064 & A/G & A & 0.85 & 44 & 35 & 0.31 & 0.24 \\
rs2065958(D3105Y) & A/C & C & 0.36 & 69 & 92 & 0.069 & 0.038 \\
rs3814299(L3970S) & A/G & A & 0.63 & 95 & 70 & 0.24 & 0.38 \\
rs12730241 & A/G & G & 0.057 & 21 & 14 & 0.051 & 0.021 \\
3321delA & A/- & del & 0.014 & 4 & 4 & 1 & 1 \\
S2554X & C/G & G & 0.021 & 10 & 4 & 0.11 & 0.16 \\
\hline
\end{tabular}


Table 2 Case-control study for atopic dermatitis (AD) in FLG polymorphisms

\begin{tabular}{|c|c|c|c|c|c|c|c|}
\hline \multirow[t]{2}{*}{ Polymorphism } & \multirow[t]{2}{*}{ Population $^{\mathrm{a}}$} & \multicolumn{3}{|c|}{ Genotype count (frequency\%) } & \multirow{2}{*}{$\begin{array}{l}\text { Genotypic } \\
P^{\mathrm{b}}\end{array}$} & \multirow{2}{*}{$\begin{array}{l}\text { Odds ratio } \\
(95 \% \mathrm{CI})^{\mathrm{c}}\end{array}$} & \multirow[t]{2}{*}{ Allelic $P^{\mathrm{b}}$} \\
\hline & & $\mathrm{C} / \mathrm{C}$ & C/A & $\mathrm{A} / \mathrm{A}$ & & & \\
\hline \multirow[t]{6}{*}{ rs2065958 } & $\mathrm{AD}$ & $58(15.6)$ & $156(41.9)$ & $158(42.5)$ & 0.94 & $1.0(0.8-1.2)$ & 0.84 \\
\hline & Only AD & $9(12.3)$ & $25(34.3)$ & $39(53.4)$ & 0.14 & $0.6(0.4-1.0)$ & 0.068 \\
\hline & $\mathrm{IgE}>1,000 \mathrm{IU} / 1$ & $30(14.2)$ & $90(42.9)$ & $90(42.9)$ & 0.89 & $1.0(0.7-1.3)$ & 0.62 \\
\hline & Early onset & $12(10.7)$ & $57(50.9)$ & $43(38.4)$ & 0.20 & $1.1(0.8-1.7)$ & 0.81 \\
\hline & Controls & $142(15.5)$ & $393(43.0)$ & $380(41.5)$ & & & \\
\hline & & $\mathrm{A} / \mathrm{A}$ & $\mathrm{A} / \mathrm{G}$ & $\mathrm{G} / \mathrm{G}$ & & & \\
\hline \multirow[t]{6}{*}{ rs3814299 } & $\mathrm{AD}$ & $2(0.5)$ & $52(13.8)$ & $322(85.7)$ & 0.64 & $1.1(0.8-1.6)$ & 0.54 \\
\hline & AD alone & $0(0)$ & $12(16.0)$ & $63(84.0)$ & 0.46 & $1.3(0.7-2.5)$ & 0.57 \\
\hline & $\operatorname{IgE}>1,000 \mathrm{IU} / 1$ & $1(0.5)$ & $34(16.1)$ & $176(83.4)$ & 0.26 & $1.4(0.9-2.0)$ & 0.21 \\
\hline & Early onset & $1(0.9)$ & $14(12.5)$ & $97(86.6)$ & 0.98 & $1.1(0.6-1.9)$ & 0.84 \\
\hline & Controls & $7(0.8)$ & $111(12.0)$ & $804(87.2)$ & & & \\
\hline & & $\mathrm{A} / \mathrm{A}$ & $\mathrm{A} /-$ & $-1-$ & & & \\
\hline \multirow[t]{6}{*}{ 3321delA } & $\mathrm{AD}$ & $356(97.3)$ & $10(2.7)$ & $0(0)$ & 0.077 & $2.1(0.9-4.9)$ & 0.077 \\
\hline & $\mathrm{AD}$ alone & $71(95.9)$ & $3(4.1)$ & $0(0)$ & 0.064 & $3.2(0.9-11.5)$ & 0.064 \\
\hline & $\mathrm{IgE}>1,000 \mathrm{IU} / 1$ & $198(95.6)$ & $9(4.4)$ & $0(0)$ & 0.0038 & $3.4(1.4-8.2)$ & 0.0036 \\
\hline & Early onset & $103(97.2)$ & $3(2.8)$ & $0(0)$ & 0.22 & $2.2(0.6-7.9)$ & 0.22 \\
\hline & Controls & $902(98.7)$ & $12(1.3)$ & $0(0)$ & & & \\
\hline & & $\mathrm{C} / \mathrm{C}$ & $\mathrm{C} / \mathrm{G}$ & $\mathrm{G} / \mathrm{G}$ & & & \\
\hline \multirow[t]{5}{*}{ S2554X } & $\mathrm{AD}$ & $365(97.3)$ & $10(2.7)$ & $0(0)$ & 0.0012 & $5.0(1.7-14.8)$ & 0.0012 \\
\hline & $\mathrm{AD}$ alone & $71(94.7)$ & $4(5.3)$ & $0(0)$ & 0.000024 & $10.3(2.7-39.4)$ & 0.000024 \\
\hline & $\operatorname{IgE}>1,000 \mathrm{IU} / 1$ & 207 (97.6) & $5(2.3)$ & $0(0)$ & 0.011 & $4.4(1.3-15.5)$ & 0.011 \\
\hline & Early onset & $110(98.2)$ & $2(1.8)$ & $0(0)$ & 0.13 & $3.3(0.6-17.4)$ & 0.13 \\
\hline & Controls & $918(99.5)$ & $5(0.5)$ & $0(0)$ & & & \\
\hline Combined & & Wild allele/wild allele & $\begin{array}{l}\text { Wild/at least } \\
\text { one null allele }\end{array}$ & Null/null & & & \\
\hline \multirow[t]{5}{*}{ (3321delA and S2554X) } & $\mathrm{AD}$ & $355(64.7)$ & $20(5.3)$ & $0(0)$ & 0.00073 & $3.0(1.5-5.8)$ & 0.00067 \\
\hline & $\mathrm{AD}$ alone & $67(90.5)$ & $7(9.5)$ & $0(0)$ & 0.000047 & $5.5(2.2-13.8)$ & 0.000042 \\
\hline & $\mathrm{IgE}>1,000 \mathrm{IU} / 1$ & $198(93.4)$ & $14(6.6)$ & $0(0)$ & 0.00015 & $3.7(1.8-7.7)$ & 0.00014 \\
\hline & Early onset & $101(95.3)$ & $5(4.7)$ & $0(0)$ & 0.054 & $2.6(1.0-7.3)$ & 0.056 \\
\hline & Controls & $900(98.1)$ & 17 (1.9) & $0(0)$ & & & \\
\hline
\end{tabular}

CI confidence interval, $\operatorname{IgE}$ immunoglobulin $\mathrm{E}$

${ }^{a} \mathrm{AD}$ alone; $\mathrm{AD}$ patients without other atopic disease. Early onset; patients whose age at disease onset was younger than 2 years

b Genotypic $P$ and allelic $P$ values were calculated with $\chi^{2}$ test in comparison with genotype and allele counts in controls, respectively

${ }^{c}$ Odds ratio for the wild type homozygote versus minor allele heterozygote and minor allele homozygote

did not reach statistical significance. In the case-control comparison, the null allele of S2554X was associated statistically significantly with AD (Table 2). S2554X was also associated with high IgE levels and the phenotype of patients with $\mathrm{AD}$ alone. Five percent of patients with the phenotype with AD alone carried the S2554X null mutation, whereas only $1 \%$ of healthy control subjects had the null mutation $\left(P=2.4 \times 10^{-5}\right)$. Three percent of $\mathrm{AD}$ patients and $4 \%$ of those with the phenotype of patients with $\mathrm{AD}$ alone carried the 3321delA allele, whereas $1 \%$ of healthy control subjects had the null mutation. However, this difference was not statistically significant $(P>0.05)$.
Association was observed between 3321delA and the highIgE phenotype $(P=0.0036)$. Combined null mutation carriers (subjects carrying either X2554 or 3321delA alleles) were observed more in patients with the $\mathrm{AD}$ and high-IgE phenotypes than in control subjects. The most significant association was observed for the phenotype of patients with $\mathrm{AD}$ alone (seven of 67 patients, carrier frequency $9.5 \%, P=4.2 \times 10^{-5}$ ). Subjects with compound heterozygous null mutations were not observed in our family or case-control samples.

To combine the TDT and case-control data, the proband of each family was selected, and an artificially constructed 
Table 3 Combined $P$ values of FLG polymorphisms in families and case-control study

\begin{tabular}{|c|c|c|c|c|c|c|c|}
\hline \multirow[t]{2}{*}{ Polymorphism } & \multicolumn{4}{|c|}{ Genotype count (frequency) } & \multirow[t]{2}{*}{ Genotypic $P^{\mathrm{a}}$} & \multirow{2}{*}{$\begin{array}{l}\text { Odds ratio } \\
(95 \% \mathrm{CI})^{\mathrm{b}}\end{array}$} & \multirow[t]{2}{*}{ Allelic $P^{\mathrm{a}}$} \\
\hline & & $\mathrm{C} / \mathrm{C}$ & $\mathrm{C} / \mathrm{A}$ & $\mathrm{A} / \mathrm{A}$ & & & \\
\hline \multirow[t]{3}{*}{ rs2065958 } & $\mathrm{AD}$ & $65(13.8)$ & $202(43.0)$ & $203(43.2)$ & 0.54 & $0.92(0.7-1.1)$ & 0.28 \\
\hline & Controls & $161(15.9)$ & $437(43.0)$ & $417(41.1)$ & & & \\
\hline & & $\mathrm{A} / \mathrm{A}$ & $\mathrm{A} / \mathrm{G}$ & $\mathrm{G} / \mathrm{G}$ & & & \\
\hline \multirow[t]{3}{*}{ rs 12730241} & $\mathrm{AD}$ & $4(0.8)$ & $60(12.6)$ & $412(86.6)$ & 0.91 & $1.1(0.8-1.5)$ & 0.69 \\
\hline & Controls & $7(0.7)$ & $124(12.1)$ & $892(87.2)$ & & & \\
\hline & & $\mathrm{A} / \mathrm{A}$ & $\mathrm{A} /-$ & $-1-$ & & & \\
\hline \multirow[t]{3}{*}{ 3323delA } & $\mathrm{AD}$ & $454(97.4)$ & $12(2.6)$ & $0(0)$ & 0.14 & $1.8(0.8-3.8)$ & 0.14 \\
\hline & Controls & $999(98.5)$ & $15(1.5)$ & $0(0)$ & & & \\
\hline & & $\mathrm{C} / \mathrm{C}$ & $\mathrm{C} / \mathrm{G}$ & $\mathrm{G} / \mathrm{G}$ & & & \\
\hline \multirow[t]{2}{*}{ S2554X } & $\mathrm{AD}$ & 459 (97.6) & $16(3.4)$ & $0(0)$ & 0.000091 & $5.0(2.1-12.3)$ & 0.0001 \\
\hline & Controls & $1010(99.3)$ & $7(0.7)$ & $0(0)$ & & & \\
\hline \multirow{3}{*}{$\begin{array}{l}\text { Combined } \\
\text { (3321delA and S2554X) }\end{array}$} & & Wild/wild & Wild/null & Null/null & & & \\
\hline & $\mathrm{AD}$ & $438(94.0)$ & $28(6.0)$ & $0(0)$ & 0.00015 & $2.9(1.6-5.1)$ & 0.00017 \\
\hline & Controls & 992 (97.8) & $22(2.2)$ & $0(0)$ & & & \\
\hline
\end{tabular}

$C I$ confidence interval

${ }^{\text {a }}$ Genotypic $P$ and allelic $P$ values were calculated with $\chi^{2}$ test in comparison with genotype and allele counts in controls, respectively

b Odds ratio for the wild type homozygote versus minor allele heterozygote and minor allele homozygote

case population consisting of parental alleles transmitted to the affected child and a control population of nontransmitted alleles in the AD family trios were determined (Kirov et al. 1999). These "cases" and "controls" in the family trios were combined with the genotype data (Table 3 ). The combined $P$ value was significant for the S2554X polymorphism and null mutations of FLG $(P=0.0001)$, whereas rs2065958 and rs12730241 were not associated with $\mathrm{AD}$ development.

\section{Discussion}

In this study, we found that the null allele of S2554X was associated with AD development, confirming previous studies showing that FLG null mutations are associated with AD (Nomura et al. 2007). Our study found 1\% of healthy subjects without any allergic diseases carried FLG null mutations, whereas a pervious study found no control subjects carried the null mutations (Nomura et al. 2007). Allele frequency of FLG null mutations in $\mathrm{AD}$ patients were similar to those reported previously (Nomura et al. 2007). Null alleles of R501X and 2282del4 were not detected in 96 Japanese AD subjects.

$F L G$ is thought to be one of the most important factors in skin-barrier function. In children, dry skin is often the earliest sign of AD. Impairment of epidermal-barrier function is a clinical hallmark of AD. Microarray analysis revealed decreased expression of FLG messenger ribonucleic acid (mRNA) in active atopic skin (Sugiura et al.
2005). These findings suggest that dysfunction of $F L G$ is an important factor in $\mathrm{AD}$ development. In our study, the most significant effect of FLG null mutations was observed in the phenotype of patients with $\mathrm{AD}$ alone. $\mathrm{AD}$ patients often suffer from other atopic diseases, such as asthma and allergic rhinitis, and patients with multiple atopic diseases exhibit increased levels of IgE against allergens. AD patients suffering from other atopic diseases are more likely to exhibit allergic skin inflammation, which leads to AD development. In contrast, because FLG plays an important role in skin-barrier function, the skin may be fragile in carriers of the FLG null allele, regardless of the atopic status of these individuals. This may result in the development of AD. Therefore, subjects with the phenotype of $\mathrm{AD}$ alone are more likely to carry the FLG null allele than those with the phenotype of $\mathrm{AD}$ along with other atopic diseases.

The study by Palmer et al. (2006) was the first to show that FLG null mutations are associated with $\mathrm{AD}$ in Caucasian populations. A number of studies have been conducted to replicate the original findings, and some have confirmed and others refuted the association of FLG with AD (Marenholz et al. 2006; Ruether et al. 2006; Weidinger et al. 2006, 2007; Barker et al. 2007; Morar et al. 2007; Stemmler et al. 2007). To examine the association of common FLG variants with $\mathrm{AD}$ development, we performed tSNP analysis of Japanese AD families and case-control subjects. Two SNPs, including one nonsynonymous mutation, were associated with AD by PDT analysis, but this finding was not confirmed in case-control subjects. The statistical 
power of the case-control study for these SNPs was more than $80 \%$ at the alpha level of 0.05 if the relative risk for $\mathrm{AD}$ in those persons carrying a putative risk allele was 1.5 compared with that in persons without the allele. Therefore, our number of case-control samples was sufficient to detect alleles confirming moderate risk but may not have been sufficient to detect alleles with weak risk.

The results of our family-based association study of S2554X did not reach statistical significance. However, the null allele of S2554X tended to be overtransmitted to affected offspring in our Japanese AD families. In the case-control comparison, X2554 was significantly associated with $\mathrm{AD}$ development, and the combined $P$ value for the family and case-control data was significant. Because of the low allele frequencies of the null alleles in $F L G$, failure to find an association in the family samples was due to low statistical power. The other null allele, 3321delA, was not associated with $\mathrm{AD}$. The allele frequency of 3321delA was very low: $2.7 \%$ in $\mathrm{AD}$ patients and $1.3 \%$ in control. Statistical power in the pedigree samples was $<0.1$ at the alpha level of 0.05 if the relative risk for $\mathrm{AD}$ in those persons carrying a putative risk allele was 2.0 compared with that in persons without the allele. In the case-control study, 567 cases would be required to achieve statistical power of 0.8 at the alpha level of 0.05 if the relative risk for $\mathrm{AD}$ in those persons carrying a putative risk allele was 2.0 compared with that in persons without the allele. Therefore, our sample size was not enough to assess the genotypic relative risk $<2$. However, combined analysis of the FLG 3321delA and S2554X null mutations showed significant association with $\mathrm{AD}$. R501X and 2282del4 were the first null mutations reported to be associated with $\mathrm{AD}$ in a European population (Irvine 2007), and a subsequent study identified three additional null alleles of FLG (R2447X, S3247X, 3702delG) associated with development of AD (Sandilands et al. 2007). These three null mutations were not found in an Asian population (Sandilands et al. 2007), whereas the3321delA and S2554X null alleles were not found in a European population (Sandilands et al. 2007). Our tSNP analysis included common missense mutations (D3105Y and L3970S), but the results were not consistent across family and case-control data. $F L G$ null mutations were also associated with high $\operatorname{IgE}$ levels. Allergens can penetrate through the skin, leading to allergic sensitization in susceptible individuals. Skin-barrier dysfunction may accelerate allergen penetration, and therefore, loss of $F L G$ function can contribute to allergic sensitization and the high-IgE phenotype.

In conclusion, FLG null alleles, not common variants, are associated with $\mathrm{AD}$ development and high IgE levels in Japanese, confirming the importance of null mutations in $F L G$ for disease onset and allergic sensitization in $\mathrm{AD}$ patients.
Acknowledgments We are grateful to Dr. Takako Takase (Takase Dermatological Clinic, Tsukuba, Japan) and Dr. Taro Mochizuki (Oho Dermatological Clinic, Tsukuba-City, Japan), Dr. Yoshihiro Nanno (Taga General Hospital, Japan), Dr. Kazuhito Hayakawa, Dr. Tetsuo Shiohara (Kyorin University School of Medicine, Japan) who provided samples and clinical data. This work was supported by Grant-in-Aid for Scientific Research from the Ministry of Health and Welfare, Japan (H17-Genome-001, EN and TA).

\section{References}

Barker JN, Palmer CN, Zhao Y, Liao H, Hull PR, Lee SP, Allen MH, Meggitt SJ, Reynolds NJ, Trembath RC, McLean WH (2007) Null mutations in the filaggrin gene (FLG) determine major susceptibility to early-onset atopic dermatitis that persists into adulthood. J Invest Dermatol 127:564-567

Barrett JC, Fry B, Maller J, Daly MJ (2005) Haploview: analysis and visualization of LD and haplotype maps. Bioinformatics 21:263265

Bradley M, Soderhall C, Luthman H, Wahlgren CF, Kockum I, Nordenskjold M (2002) Susceptibility loci for atopic dermatitis on chromosomes 3,13,15, 17 and 18 in a Swedish population. Hum Mol Genet 11:1539-1548

Candi E, Schmidt R, Melino G (2005) The cornified envelope: a model of cell death in the skin. Nat Rev Mol Cell Biol 6:328340

Compton JG, DiGiovanna JJ, Johnston KA, Fleckman P, Bale SJ (2002) Mapping of the associated phenotype of an absent granular layer in ichthyosis vulgaris to the epidermal differentiation complex on chromosome 1. Exp Dermatol 11:518-526

Cookson WO, Ubhi B, Lawrence R, Abecasis GR, Walley AJ, Cox HE, Coleman R, Leaves NI, Trembath RC, Moffatt MF, Harper JI (2001) Genetic linkage of childhood atopic dermatitis to psoriasis susceptibility loci. Nat Genet 27:372-373

Dale BA, Resing KA, Lonsdale-Eccles JD (1985) Filaggrin: a keratin filament associated protein. Ann N Y Acad Sci 455:330-342

de Bakker PI, Yelensky R, Pe'er I, Gabriel SB, Daly MJ, Altshuler D (2005) Efficiency and power in genetic association studies. Nat Genet 37:1217-1223

Enomoto H, Noguchi E, Iijima S, Takahashi T, Hayakawa K, Ito M, Kano T, Aoki T, Suzuki Y, Koga M, Tamari M, Shiohara T, Otsuka F, Arinami T (2007) Single nucleotide polymorphismbased genome-wide linkage analysis in Japanese atopic dermatitis families. BMC Dermatol 7:5

Gan SQ, McBride OW, Idler WW, Markova N, Steinert PM (1990) Organization, structure, and polymorphisms of the human profilaggrin gene. Biochemistry 29:9432-9440

Haagerup A, Bjerke T, Schiotz PO, Dahl R, Binderup HG, Tan Q, Kruse TA (2004) Atopic dermatitis-a total genome-scan for susceptibility genes. Acta Derm Venereol 84:346-352

Hanifin J, Rajka G (1980) Diagnostic feature of atopic dermatitis. Acta Derm Venereol (Suppl) 92:44-47

Irvine AD (2007) Fleshing out filaggrin phenotypes. J Invest Dermatol 127:504-507

Kirov G, Jones I, McCandless F, Craddock N, Owen MJ (1999) Family-based association studies of bipolar disorder with candidate genes involved in dopamine neurotransmission: DBH, DAT1, COMT, DRD2, DRD3 and DRD5. Mol Psychiatry 4:558-565

Larsen FS, Holm NV, Henningsen K (1986) Atopic dermatitis. A genetic-epidemiologic study in a population-based twin sample. J Am Acad Dermatol 15:487-494

Lee YA, Wahn U, Kehrt R, Tarani L, Businco L, Gustafsson D, Andersson F, Oranje AP, Wolkertstorfer A, v Berg A, Hoffmann 
U, Kuster W, Wienker T, Ruschendorf F, Reis A (2000) A major susceptibility locus for atopic dermatitis maps to chromosome 3q21. Nat Genet 26:470-473

Levy RM, Gelfand JM, Yan AC (2003) The epidemiology of atopic dermatitis. Clin Dermatol 21:109-115

Listwan P, Rothnagel JA (2004) Keratin bundling proteins. Methods Cell Biol 78:817-827

Marenholz I, Nickel R, Ruschendorf F, Schulz F, Esparza-Gordillo J, Kerscher T, Gruber C, Lau S, Worm M, Keil T, Kurek M, Zaluga E, Wahn U, Lee YA (2006) Filaggrin loss-of-function mutations predispose to phenotypes involved in the atopic march. J Allergy Clin Immunol 118:866-871

Mischke D, Korge BP, Marenholz I, Volz A, Ziegler A (1996) Genes encoding structural proteins of epidermal cornification and S100 calcium-binding proteins form a gene complex ("epidermal differentiation complex") on human chromosome 1q21. J Invest Dermatol 106:989-992

Morar N, Cookson WO, Harper JI, Moffatt MF (2007) Filaggrin mutations in children with severe atopic dermatitis. J Invest Dermatol 127:1667-1672

Morar N, Willis-Owen SA, Moffatt MF, Cookson WO (2006) The genetics of atopic dermatitis. J Allergy Clin Immunol 118:24-34 (quiz 35-26)

Nomura T, Sandilands A, Akiyama M, Liao H, Evans AT, Sakai K, Ota M, Sugiura H, Yamamoto K, Sato H, Palmer CN, Smith FJ, McLean WH, Shimizu H (2007) Unique mutations in the filaggrin gene in Japanese patients with ichthyosis vulgaris and atopic dermatitis. J Allergy Clin Immunol 119:434-440

Nystad W, Roysamb E, Magnus P, Tambs K, Harris JR (2005) A comparison of genetic and environmental variance structures for asthma, hay fever and eczema with symptoms of the same diseases: a study of Norwegian twins. Int J Epidemiol 34:13021309

Palmer CN, Irvine AD, Terron-Kwiatkowski A, Zhao Y, Liao H, Lee SP, Goudie DR, Sandilands A, Campbell LE, Smith FJ, O'Regan GM, Watson RM, Cecil JE, Bale SJ, Compton JG, DiGiovanna JJ, Fleckman P, Lewis-Jones S, Arseculeratne G, Sergeant A, Munro CS, El Houate B, McElreavey K, Halkjaer LB, Bisgaard H, Mukhopadhyay S, McLean WH (2006) Common loss-offunction variants of the epidermal barrier protein filaggrin are a major predisposing factor for atopic dermatitis. Nat Genet 38:441-446

Ruether A, Stoll M, Schwarz T, Schreiber S, Folster-Holst R (2006) Filaggrin loss-of-function variant contributes to atopic dermatitis risk in the population of Northern Germany. Br J Dermatol 155:1093-1094

Sandilands A, O'Regan GM, Liao H, Zhao Y, Terron-Kwiatkowski A, Watson RM, Cassidy AJ, Goudie DR, Smith FJ, McLean
WH, Irvine AD (2006) Prevalent and rare mutations in the gene encoding filaggrin cause ichthyosis vulgaris and predispose individuals to atopic dermatitis. J Invest Dermatol 126:17701775

Sandilands A, Terron-Kwiatkowski A, Hull PR, O'Regan GM, Clayton TH, Watson RM, Carrick T, Evans AT, Liao H, Zhao Y, Campbell LE, Schmuth M, Gruber R, Janecke AR, Elias PM, van Steensel MA, Nagtzaam I, van Geel M, Steijlen PM, Munro CS, Bradley DG, Palmer CN, Smith FJ, McLean WH, Irvine AD (2007) Comprehensive analysis of the gene encoding filaggrin uncovers prevalent and rare mutations in ichthyosis vulgaris and atopic eczema. Nat Genet 39:650-654

Smith FJ, Irvine AD, Terron-Kwiatkowski A, Sandilands A, Campbell LE, Zhao Y, Liao H, Evans AT, Goudie DR, Lewis-Jones S, Arseculeratne G, Munro CS, Sergeant A, O’Regan G, Bale SJ, Compton JG, DiGiovanna JJ, Presland RB, Fleckman P, McLean WH (2006) Loss-of-function mutations in the gene encoding filaggrin cause ichthyosis vulgaris. Nat Genet 38:337-342

Stemmler S, Parwez Q, Petrasch-Parwez E, Epplen JT, Hoffjan S (2007) Two common loss-of-function mutations within the filaggrin gene predispose for early onset of atopic dermatitis. J Invest Dermatol 127:722-724

Sugiura H, Ebise H, Tazawa T, Tanaka K, Sugiura Y, Uehara M, Kikuchi K, Kimura T (2005) Large-scale DNA microarray analysis of atopic skin lesions shows overexpression of an epidermal differentiation gene cluster in the alternative pathway and lack of protective gene expression in the cornified envelope. Br J Dermatol 152:146-149

Weidinger S, Illig T, Baurecht H, Irvine AD, Rodriguez E, DiazLacava A, Klopp N, Wagenpfeil S, Zhao Y, Liao H, Lee SP, Palmer CN, Jenneck C, Maintz L, Hagemann T, Behrendt H, Ring J, Nothen MM, McLean WH, Novak N (2006) Loss-offunction variations within the filaggrin gene predispose for atopic dermatitis with allergic sensitizations. J Allergy Clin Immunol 118:214-219

Weidinger S, Rodriguez E, Stahl C, Wagenpfeil S, Klopp N, Illig T, Novak N (2007) Filaggrin mutations strongly predispose to early-onset and extrinsic atopic dermatitis. J Invest Dermatol 127:724-726

Williams H, Robertson C, Stewart A, Ait-Khaled N, Anabwani G, Anderson R, Asher I, Beasley R, Bjorksten B, Burr M, Clayton T, Crane J, Ellwood P, Keil U, Lai C, Mallol J, Martinez F, Mitchell E, Montefort S, Pearce N, Shah J, Sibbald B, Strachan D, von Mutius E, Weiland SK (1999) Worldwide variations in the prevalence of symptoms of atopic eczema in the international study of asthma and allergies in childhood. J Allergy Clin Immunol 103:125-138 